\title{
COVID-19 ve Hipertansiyon
}

\author{
Işılay TAŞKALDIRAN ${ }^{1}$ ৫, Taner BAYRAKTAROĞLU² $\bullet$ \\ ${ }^{1}$ Zonguldak Atatürk Devlet Hastanesi, Endokrinoloji ve Metabolizma Hastalıkları Bölümü, Zonguldak, Türkiye \\ ${ }^{2}$ Zonguldak Bülent Ecevit Üniversitesi, Tıp Fakültesi, Endokrinoloji ve Metabolizma Hastalıkları Bilim Dalı, Zonguldak, Türkiye \\ Bu makaleye yapılacak atıf: Taşkaldıran I, Bayraktaroğlu T. COVID-19 ve Hipertansiyon. Türk Diyab Obez 2020;2: 155-159.
}

\begin{abstract}
ÖZ
Çin'de, ilk kez 31 Aralık 2019'da, yeni bir ciddi akut solunum sendromu koronavirüs 2 (SARS-CoV-2)'nin neden olduğu COVID-19 enfeksiyonu tespit edildi ve pandemiye sebep oldu. Hipertansiyon (HT), COVID-19 enfeksiyonunda prognozu etkileyen önemli bir komorbidite olarak karşımıza çıkmaktadır. SARS-CoV-2'nin akciğerde viral giriş reseptörü olarak anjiyotensin dönüştürücü enzim 2'yi ('angiotensin converting enzyme-2', ACE2) kullanması, COVID-19 enfeksiyonunda hipertansiyon tanısı olan ve ACEI/ARB tedavisi alan hastalar açısından endişe yaratmıştır. Yapılan çalışmalarda HT tanısı olan COVID-19 hastalarında hastalığın daha ciddi ve daha mortal seyrettiği görülmektedir. ACEI/ARB kullanım gruplarında birçok çalışmada prognoz açısından farklılık oluşturmadığı hatta bazı çalışmalarda olumlu etki oluşturduğu izlenmektedir. Ayrıca diğer antihipertansif tedavilerin de prognoz veya mortalite açısından anlamlı farklılık yaratmadığı görülmektedir. Hipertansif hastaların kan basıncı mutlaka kontrol altında tutulmalıdır. Başka bir neden yoksa hastaların antihipertansif tedavileri değiştirilmemelidir.
\end{abstract}

Anahtar Sözcükler: COVID-19, Hipertansiyon, Prognoz, Mortalite

\section{The COVID-19 and Hypertension}

\begin{abstract}
On 31 December 2019, a novel severe acute respiratory syndrome coronavirus 2 (SARS-CoV-2) was detected in China, caused COVID-19 infection and a pandemic. Hypertension (HT) appeared as an important comorbidity affecting prognosis in COVID-19 infection. SARSCoV-2's use of angiotensin converting enzyme 2 ('angiotensin converting enzyme-2', ACE2) as viral entry receptor in the lung has caused concern in patients diagnosed with hypertension and receiving ACEI / ARB therapy in COVID-19 infection. Studies show that the disease is more serious and more mortal in HT patients diagnosed with COVID-19. Taking ACEI / ARB, does not differ prognosis and mortality in many studies and even has positive effects in some studies. In addition, it seems that other antihypertensive treatments do not make a significant difference in terms of prognosis or mortality. Blood pressure of hypertensive patients must be kept under control. If there is no other reason, antihypertensive treatments of patients should not be changed.
\end{abstract}

Key Words: COVID-19, Hypertension, Prognosis, Mortality

\section{Gíriș}

Çin'in Hubei Eyaleti Wuhan'da, 31 Aralık 2019'da, kaynağı bilinmeyen pnömoni vakaları bildirilmeye başlandı. 9 Ocak 2020'de Çin Hastalık Kontrol ve Önleme Merkezi, etkenin yeni bir ciddi akut solunum sendromu koronavirüs 2 (SARS-CoV-2) olduğunu bildirdi. SARS-CoV-2'nin neden olduğu hastalık daha sonra COVID-19 olarak adlandırıldı (1). Dünya Sağlık Örgütü (WHO) 11 Mart 2020'de COVID19 salgınını pandemi olarak kabul etti (2).
COVID-19'a neden olan koronavirüsün, şiddetli akut solunum sendromu virüsü (SARS) ile aynı alt cins içinde bir betacoronavirüs olduğu gösterilmiştir. Reseptör bağlayan gen bölgesinin yapıs1, SARS koronavirüsünün yapısına çok benzer olup, virüsün, hücre girişi için aynı reseptörü anjiyotensin dönüştürücü enzim 2'yi (ACE2) kullandığ gösterilmiştir (3).

Tüm Dünyayı derinden etkileyen SARS-CoV-2 enfeksiyonunun klinik bulguları, asemptomatik hastalıktan başlayıp, hafif üst solunum yolu enfeksiyonu, tat ve koku kaybı,

ORCID: Işlay Taşkaldıran / 0000-0002-1390-7571, Taner Bayraktaroğlu / 0000-0003-3159-6663 
solunum yetmezliğinin eşlik ettiği ciddi viral pnömonilere varan geniş spektrumda değişmektedir (1). İleri yaş hasta grubunda ve altta tıbbi komorbiditesi olanlarda genel olarak hastalık daha ciddi seyretmektedir. Ciddi hastalık ve mortalite ile ilişkili risk faktörleri arasında; 65 yaş üstü, kardiyovasküler hastalık $(\mathrm{KVH})$, diabetes mellitus $(\mathrm{DM})$, hipertansiyon (HT), kronik akciğer hastalığı, kanserler, kronik böbrek hastalığ $(\mathrm{KBH})$, immünsüpresif veya biyolojik ajan kullanımı, obezite ve sigara yer alır (4).

SARS-CoV-2'nin hipertansif hastalarda ciddi hastalık riskinin fazla olduğuna dair veriler, aynı zamanda akciğer hücrelerinde viral giriş reseptörü olarak anjiyotensin dönüştürücü enzim 2'yi ('angiotensin converting enzyme-2', ACE2) kullanması, toplumdaki hipertansiyon prevalansı ve renin-anjiyotensin sistem (RAS) blokörleri kullanım sıklığ 1 da birlikte değerlendirildiğinde COVID-19 enfeksiyonu ve hipertansiyon birlikteliği önemli bir konu olarak gündeme gelmiştir (5). Bu makalede COVID-19 enfeksiyonu hipertansiyon hastaları açısından güncel bilgiler ışı̆̆ında ele alınmıştır.

\section{Hipertansiyon COVID-19 Enfeksiyonu İçin Bir Risk Faktörü Müdür?}

Hipertansiyon ve enfeksiyon, özellikle pnömoni ilişkisi daha önceki yıllarda da değerlendirilmiş bir konudur. Çünkü pnömoni ile hastaneye yatırılan hastalarda hipertansiyon sık görülen bir komorbidite olarak karşımıza çıkmaktadır. Bu birliktelikte hem hipertansiyon hem de pnömoni sıklığının ileri yaşta belirgin olarak artışının etkisi olmuştur. İspanya'da yapılmış bir çalışmaya göre hipertansiyonunun toplum kökenli pnömoni insidansında anlamlı bir etkisi bulunmamıştır (6). Başka bir çalışmada da yaş, alkol alımı, diyabet pnömoni açısından bağımsız risk faktörü olarak değerlendirilirken, hipertansiyon pnömoni açısından bir risk faktörü olarak değerlendirilmemiştir (7). Çin'de COVID-19 enfeksiyonları teşhisi konulan 20982 hastanın değerlendirmesinin yapıldığ belirtilen hipertansiyon oranı \% 12.6 idi. Bu da Çin'deki nüfus verilerine (\% 10.9) benzer olarak değerlendirilmiştir. Bu çalışmada hayatını kaybetmiş 406 hastada, hipertansiyon oranı \% 39.7 idi. Ancak bu hayatını kaybetmiş hastaların \%81'i 60 yaşın üzerinde olup, buradaki hipertansiyon sıklığı ileri yaş ile hipertansiyon sıklığının artmasına bağlanmıştır $(8,9)$. İtalya' da 1591 COVID-19 hastası üzerinde yapılmış çalışmada 21-40 yaş arası hastaların \%11'inde HT tanısı varken, 41-50 yaş grubunda \%26, 71-80 yaş grubunda $\% 62$, 81-90 yaş grubunda \%75 HT tanısı izlenmiştir (10). Çin'de 1590 hastanın değerlendirildiği çalışmada da hipertansiyon sıklığı \%16.9 bulunmuştur (11). Bu değerler genel toplum sıklığından çok farklı olmayıp ve hipertansiyon sıklığının yaş ile artmasına bağlanmıştır.
Hipertansiyon sıklığı yaş ile birlikte artmaktadır. Güncel veriler 1şı̆̆ında hipertansiyonun, COVID-19 riskini artırdığına dair kesin kanıtlar mevcut değildir (5).

\section{Renin - Anjiyotensin Sistemi ve ACE-2}

Renin-anjiyotensin sistemi (RAS), elektrolit dengesini ve kan basıncını düzenlemede önemli rol oynamakla birlikte, aynı zamanda akciğer de dahil olmak üzere birçok organın işlevini etkileyen ek fonksiyonlara sahip karmaşık bir sistemdir (Şekil 1). RAS iki yol içerir: ACE / Anjiotensin II / AT1R yolu ve ACE2 / Anjiotensin (1-7) / Mas reseptör yolu. Fizyolojik koşullar altında, bu iki yol dinamik bir denge durumundadır (12). Anjiotensin I den ACE ile anjiyotensin II üretilir. Anjiyotensin II sempatik sinir sistemini aktive ederek, vazokonstriksiyona neden olur, kan basıncinı artırır ve inflamasyona ve miyokardiyal hipertrofiye yol açar. RAS içindeki önemli bir karşı düzenleme yolu da RAS'ın klasik Anjiotensin II etkisini dengeleyen ACE2'dir. ACE2 esas olarak Anjiotensin II düzeylerini azaltarak vazodilatasyona neden olur. Aynı zamanda ACE2, nitrik oksit salınımı ve barorefleks duyarlılığının aktivasyonu ile birlikte, kardiyovasküler sistem, böbrek ve diğer organlarda doku hasarına karşı koruyucu etkisi vardır $(12,13)$.

ACE ve ACE2 arasındaki benzerliklere rağmen, bu iki enzimin fonksiyonları tamamen farklıdır. ACE2, kalp, böbrekler, akciğerler, testislerde ve gastointestinal sistemde yaygın olarak bulunur. Ayrica insan ACE2, burun ve trakeobronşiyal dokuların siliyer hava yolu epitel hücrelerinde de mevcuttur (14)

Normalde, ACE2 akut akciğer hasarı üzerinde koruyucu bir etkisi vardır. Yapılan hayvan çalışmalarında, akut akciğer hasarında ve ARDS de ACE2'nin 'down'-regülasyonu gösterilmiştir (5). ACE2 gen eksikliği olan farelerde daha ciddi solunum yolu enfeksiyonu görülürken, ACE gen eksikliği

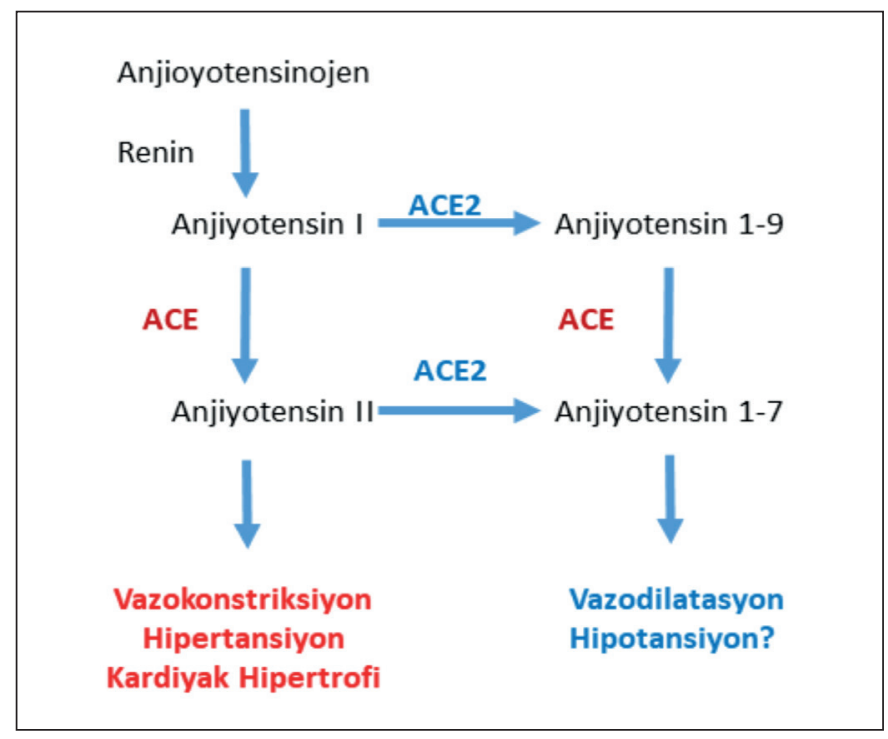

Şekil 1: Renin-Anjiotensin sistemi 
olan farelerde tam tersi akut akciğer hasarı semptomlarında iyileşme izlenmiştir (15). Bu bilgiler sşı̆̆ında ACEI'ler ve ARB'ler ile tedavinin SARS-CoV-2 enfeksiyonundaki rolü tartışılmaya başlanmıştır. Çünkü SARS-CoV-2, insan alveoler epitel hücrelerini istila etmek için ACE2 reseptörünü kullanır. ACE2, ACEI'lerin doğrudan bir hedefi değildir. Bununla birlikte, bazı çalışmalarda ARB'ler veya ACEI'ler ile tedavi sırasında ACE2'nin up-regülasyonunu gösteren çalışmalar olmakla beraber, veriler net değildir. Şu ana kadar, RAS blokörlerinin solunum yollarındaki doku ACE2 aktivitesi üzerindeki etkileri hakkında bir çalışma bildirilmemiştir (5).

\section{Hipertansiyonun COVID-19 Enfeksiyonunda Prognoza} Etkisi Nedir?

Hipertansiyon hastalarında hastalık seyrinin daha ciddi ve mortalite oranlarının fazla olması ile ilgili çeşitli görüşler bildirilmiştir. Hipertansif hastalara daha fazla kardiyovasküler komplikasyonun eşlik etmesi bunlardan biridir. Ayrıca herhangi bir tedavi almayan grupta mortalite ve prognozun tedavi alan gruba göre daha kötü bulunması kontrolsüz kan basıncının etkisini düşündürmektedir.

Çin'de 1590 COVID-19 hastasını değerlendiren çalışmada \%16.9'unda HT tanısı eşlik etmekteydi. Ciddi vakalarda HT prevalansı daha fazla izlenmiştir. (\%12.6-32.7). Benzer şekilde yoğun bakım ihtiyacı, invaziv mekanik ventilatör ihtiyacı ve ölüm oranları HT olan grupta daha fazla izlenmiştir (\%19.7- \%5.9). Sonuç olarak bu çalışmada HT'un hastalık ciddiyetinde ve mortalitede kötü prognostik belirteç olduğu belirtilmiştir (11). Toplam altı çalışmada 1527 hastanın değerlendirildiği bir meta analizde HT sıklığı ortalama \%17.1 saptanmış. Ciddi hastalık grubunda hipertansiyon sıklı̆̆ 1 yaklaşık iki kat daha fazla izlenmiştir (\%28.8-\%14.1) (16).

Gao ve ark.nın 2877 hastanın retrospektif değerlendirdiği çalışmada hipertansiyon sıklığ $\% 29.5$ saptanmış. Hastaların $(\mathrm{n}=850)$ yaklaşı $\%$ 4'ü ve HT tanısı olmayan hastaların $(\mathrm{n}=2027)$ \%1.1'inin hayatını kaybettiği bildirilmiştir. Hipertansiyon tanısı olan hastalarda mortalite oranları istatistiksel olarak anlamlı ölçüde $(\mathrm{p}<0.001)$ daha fazla izlenmiştir. Bu çalışmada, HT tanısı olan hastalarda ciddi hastalık oranı ve mekanik ventilasyon ihtiyacının daha fazla olduğu belirtilmiștir. Ayrıca bu çalışmada hipertansiyon hastalarında, herhangi bir antihipertansif tedavi almayan grupta (11/140), antihipertansif tedavi alan gruba göre (23/710) mortalite oranı anlamlı derecede yüksek olduğu bildirilmiştir (sırası ile \%7.9 ve \%3.3, p= 0.012) (17).

Virüsün tromboemboli komplikasyonlarını ve prokoagülan durumu da prognoz ve mortalite üzerinde önemli olduğu görülmüştür (18). Hipertansiyonun da hiperkoagülopati ile ilişkili olduğu daha önceki çalışmalarda da gösterilmiştir. COVID-19 ve HT birlikte ise trombotik sürecin kötüleşmesi mümkündür (19). Bu da HT’un COVID-19 prognozuna olumsuz etkisinin nedenlerinden biri olabilir.

$\mathrm{Bu}$ veriler ışığında HT tanısı olan COVID-19 enfeksiyon hastalarında prognozun olumsuz etkilendiği görülmektedir. Hastalığın daha ciddi ve daha mortal seyrettiği çalışmalarda gösterilmiştir. $\mathrm{Bu}$ durumda birçok farklı patogenetik mekanizmanın rol oynadığ düşünülmektedir.

\section{Antihipertansif İlaçların COVID-19 Enfeksiyonunda Prognoza Etkisi Nedir?}

SARS-CoV-2 virüsü için hücresel reseptör olan ACE2 nin kullanıldığının anlaşılması üzerine özellikle hipertansiyon hastalarında ACE inhibitörlerinin (ACEI) ve Anjiyotensin Reseptör Blokörlerinin (ARB) kullanımı tartışma yaratmıştır. $\mathrm{Bu}$ tartışmanın temelinde, ACEI'lerin/ARB'lerin SARS-CoV-2 virüsü için hücresel reseptör olan ACE2 ekspresyonunu artırıp artırmaması ve muhtemelen enfeksiyon şiddeti yeralmaktadır.

Çin'de Meng ve ark.nın yaptığ çalışmada 417 COVID-19 hastasından 51 hastanın (\%12.23) HT tanısı aldığ1 gözlenmiștir. Dokuz hasta antihipertansif tedavi almazken, 17 hasta ACEI/ARB almakta ve 25 hasta da diğer antihipertansif tedavileri almaktayd. ACEI/ARB grubunda sadece dört hastada (\%23) hastalık ciddi seyrederken, ACEI/ARB almayan 12 hastada (\%48) hastalık ciddi seyretmiş ve bir hasta yaşamını kaybetmiştir. Hasta sayısının az olması çalışmanın dezavantajıdır. Bu çalışmada RAS inhibitörü kullanımının ciddi hastalık ve mortalite üzerine olumlu etkisi gösterilmiştir. Bu sonuçta ACEI/ARB kullanımının inflamatuvar sitokinleri azaltıcı etkisinin de bir faktör olabileceği belirtilmiştir (20).

Ayrıca Çin'de 1128 HT tanısı olan COVID-19 hastası retrospektif olarak incelenmiş. Bu hastaların 188'i, ACEI/ ARB kullanırken 940 hasta non ACEI/ARB tedavisi almaktaymış. ACEI/ARB grubunda mortalite non-ACEI/ ARB grubuna göre daha az bulunmuş ( sırasıyla \%3.7 - 9.8, $\mathrm{p}=0.01)$. Bu çalışmada ACEI/ARB grubunda mortalitenin daha az olmasının nedeninin anlaşılabilmesi için daha fazla ve daha kapsamlı çalıșmalara ihtiyaç olduğu belirtilmiștir. Bununla beraber RAS blokajı ile inflamasyonun azalabileceği ve ACE2 ekspresyonunun artabileceği, ACE2 artışının da ARDS riskini azalttı̆̆ hipotezi de savunulmuştur (21).

Benzer şekilde Çin'de 1178 hastanın retrospektif değerlendirildiği bir çalışmada, hipertansif hastalar ACEI/ARB kullanımı ciddi ve ciddi olmayan hastalık durumu ile karşılaştırılmıştır. Hastaların \%30.7'sinde HT olduğu, ACEI/ ARB kullanım oranlarının ağır ve ağır olmayan hastalar arasında farklılık görülmediği belirtilmiştir (sırası ile \%32.9 ve \%30.7; $\mathrm{p}=0.65$ ). ACEI/ARB kullanım oranları aynı zamanda hayatını kaybeden ve sağ kalan grupta da istatistiksel olarak 
anlamlı oranda farklı saptanmamıștır (sırası ile $\% 27.3$ ve \%33.0; $\mathrm{p}=0.34$ ). Bu çalışmada aynı zamanda diğer antihipertansif tedavi grupları ve kombine antihipertansif tedaviler de prognoz açısından değerlendirilmiştir. Kalsiyum kanal blokörü ve beta blokör kullanım oranlarında da ağır hasta ve ağır olmayan hasta grupları arasında farklılık izlenmemiş (22). Sonuç olarak bu çalışma ACEI/ARB'lerin ve diğer antihipertansif tedavilerin COVID-19 enfeksiyonun şiddeti veya mortalitesi ile ilişkili olmadığını düşündürmektedir.

New York'da 5700 COVID-19 hastasının değerlendirmesinde hipertansiyon prevalansı \% 56.6 gibi yüksek oranda izlenmiștir. Mortalite oranları ACEI/ARB almayanda \%26.7, ACEI alanda \%32.7, ARB alanda \%30.6 saptanmıștır (23).

Gao ve ark.nın çalışmasında toplam 710 antihipertansif tedavi alan COVID-19 hastasının 183'ü (\%25,7) RAS inhibitörü kullanırken, 527 hasta (\%74.2) RAS inhibitörü dışı (kalsiyum kanal blokörü, beta blokör, diüretik) tedavi aldığı belirtilmiştir. RAS inhibitörü kullananlarda kullanmayana göre mortalite daha az izlenmekle beraber anlamlı bulunmamıștır (sırası ile $\% 2.2$ ve $\% 3.6 ; \mathrm{p}=0.774)$. Bu iki grupta hastalık ciddiyeti, mekanik ventilasyon ihtiyacı ve taburculuk süresi karşılaştırmasında da anlamlı farklılık saptanmamıştır (17).

Pirola ve ark.nın yaptığı toplamda 16 çalışmada 24676 hastanın değerlendirildiği bir meta analizde; hastalar kritik hasta $(n=4134)$ ve kritik olmayan hasta $(n=20542)$ olarak gruplandırılmıştır. ACEI/ARB kullanımının COVID-19 enfeksiyonu olan hipertansif hastalarda daha yüksek mortalite veya ciddi hastalık riski ile ilişkili olmadığg 1 gösterilmiș. Tam tersi ACEI/ARB kullanımının mortalite ve kritik hastalık riskinde azalma sağladığı gösterilmiştir (24).

ACEI/ARB kullanım gruplarında SARS-CoV-2 virüsü hücresel reseptör olarak ACE2 reseptörünü kullanmasına rağmen, prognoz açısından çalışmalarda genel olarak farklılık saptanmadı. Bazı çalışmalar ACEI/ARB kullanımının prognoz açısından olumlu etkisi görüldü. Sonuç olarak ACEI/ ARB kullanımın en azından prognoz açısından olumsuz etkisi olmadığı söylenebilir. ACEI/ARB kullanımının prognoz ve mortalite üzerine olumlu etkisi bazı çalışmalarda gösterilmiş olsa da net konuşabilmek için daha fazla çalışmalara ihtiyaç duyulmaktadır. Çalışmalar daha çok ACEI/ ARB ile yapılmış olmasına rağmen çalışmalarda diğer antihipertansif tedavilerin de prognoz veya mortalite açısından anlamlı farklılık yaratmadığ 1 görülmektedir.

\section{COVID-19 Enfeksiyonunda Antihipertansif Tedavi Değiştirilmeli Midir?}

Mancia ve ark.nın yaptığ 1 çalışmada 6272 COVID-19 hastas1, 30759 benzer özellikte kontrol grubu ile karşılaştırılmıştır. Kullanılan antihipertansif tedaviler değerlendirilmiş. ACEI ve ARB'lerin kullanımı, Covid-19 hastalarında kontrol gru- buna göre daha sık izlenmiş (ACEI kullanımı hasta grubunda $\% 23.9$, kontrol grubunda \%21.4, ARB kullanımı hasta grubunda \% 22.2, kontrol grubunda \%19.2). Bununla birlikte, ACEI veya ARB'lerin COVID-19 riskini etkilediğine dair bir kanıt izlenmemiştir. Benzer şekilde kalsiyum kanal blokörleri, beta blokörler, diüretkler ve diğer antihipertansif tedaviler karşılaştırıldığında da hasta grubunda kontrol grubuna göre bir miktar daha sik kullanım izlense de COVID-19 enfeksiyonu ile ilişkili bir risk izlenmemiştir (25).

COVID-19 enfeksiyonu ve hipertansiyonun değerlendirildiği bir derlemede RAS inhibitörlerinin kesilmesi veya değiștirilmesinin gerekliliği konusunda net kanıt sunulmamış olup, RAS inhibitörlerinin kesilmesi COVID-19 hastalarında daha fazla komplikasyona neden olabilecek kontrolsüz hipertansiyon ve kardiyak fonksiyon bozukluğu gibi birçok dezavantajı olacağı belirtilmiştir (26).

Avrupa Kardiyoloji Derneği Hipertansiyon Konseyi'nin (The Council on Hypertension of the European Society of Cardiology, ESC) önerisi ile de birlikte güncel veriler ışı̆ı̆ında başka bir neden yoksa hastaların mevcut antihipertansif tedavileri kesilmemeli ve değiştirilmemelidir (27).

\section{SONUÇ}

Hipertansiyon, COVID-19 enfeksiyonu için mortaliteyi ve hastalık ciddiyetini önemli ölçüden etkileyen sık görülen bir komorbiditedir. ACEI/ARB kullanımı SARS-CoV2'nin ACE2 aracılı̆̆ ile hücreye girmesi nedeni ile endişe yaratmıștır. Ancak yapılan çalışmalarda ACEI/ARB kullanımının hastalık prognozu ve mortalite üzerine zararı görülmemiştir. Hatta bazı çalışmalarda ACEI/ARB kullanımının prognoz ve mortalite üzerine olumlu etkisi olduğu gösterilmiştir. Ayrıca diğer antihipertansif tedavilerin de prognoz ve mortalite üzerine etkileri saptanmamıştır. Güncel veriler doğrultusunda hipertansif hastaların kan basıncı kontrol altında tutulmalıdır. Başka bir neden yoksa mevcut antihipertansif tedavilerine devam edilmelidir.

\section{Etik Kurul Onayı}

Deneysel ve insan ürünü kullanılmadığından etik kurul oluru gerekmemiştir.

Çıkar Çatışması

Yazarların bu araştırma ve makale için herhangi bir çıkar çatışması yoktur.

Finansal Destek

$\mathrm{Bu}$ araştırma için mali destek alınmamıştır.

Yazarların Makaleye Katkı Beyanı

Fikir ve tasarım, Literatür tarama ve veri toplama, Yorum ve Eleştirel Yaklaşım, Yazıma yazarların katkısı eşit orandadır.

Hakem Değerlendirmesi

Hakemlerin Değerlendirmeleri sonrası yayınlanmaya uygun bulunmuş ve kabul edilmiştir. 


\section{KAYNAKLAR}

1. Zhu N, Zhang D, Wang W, Li X, Yang B, Song J, Zhao X, Huang B, Shi W, Lu R, Niu P, Zhan F, Ma X, Wang D, Xu W, Wu G, Gao GF, Tan W; China Novel Coronavirus Investigating and Research Team. A novel coronavirus from patients with pneumonia in China, 2019. N Engl J Med. 2020; 382:727-733.

2. http://www.euro.who.int/en/health-topics/healthemergencies/coronavirus-covid-19/ news/news/2020/3/whoannounces-covid-19-outbreak-a-pandemic. (30 March 2020)

3. Zhou P, Yang XL, Wang XG, et al. A pneumonia outbreak associated with a new coronavirus of probable bat origin. Nature. 2020;579(7798):270-273.

4. Zhou F, Yu T, Du R, et al. Clinical course and risk factors for mortality of adult inpatients with COVID-19 in Wuhan, China: A retrospective cohort study. Lancet. 2020;395(10229):10541062.

5. Kreutz R, Algharably EAE, Azizi M, et al. Hypertension, the renin-angiotensin system, and the risk of lower respiratory tract infections and lung injury: Implications for COVID-19 Cardiovasc Res. 2020;cvaa097.

6. Gutierrez F, Masia M, Mirete C, Soldan B, Rodriguez JC, Padilla S, Hernandez I, Royo G, Martin-Hidalgo A. The influence of age and gender on the populationbased incidence of community-acquired pneumonia caused by different microbial pathogens. J Infect. 2006;53:166-174.

7. Koivula I, Sten M, Makela PH. Risk factors for pneumonia in the elderly. Am J Med. 1994;96:313-320.

8. Wang Z, Chen Z, Zhang L, Wang X, Hao G, Zhang Z, Shao L, Tian Y, Dong Y, Zheng C, Wang J, Zhu M, Weintraub WS, Gao R. Status of hypertension in China: Results from the China Hypertension Survey, 2012-2015. Circulation. 2018;137:23442356.

9. The epidemiological characteristics of an outbreak of 2019 novel coronavirus diseases (COVID-19) in China. Zhonghua Liu Xing Bing Xue Za Zhi. 2020;41:145-151.

10. Grasselli G, Zangrillo A, Zanella A, et al. Baseline Characteristics and Outcomes of 1591 Patients Infected With SARS-CoV-2 Admitted to ICUs of the Lombardy Region, Italy. JAMA. 2020;323(16):1574-1581.

11. Guan WJ, Liang WH, Zhao Y, et al. Comorbidity and its impact on 1590 patients with COVID-19 in China: A nationwide analysis. Eur Respir J. 2020;55(5):2000547.

12. Hampl V, Herget J, Bíbová J, et al. Intrapulmonary activation of the angiotensin-converting enzyme type 2/angiotensin 1-7/G-protein-coupled Mas receptor axis attenuates pulmonary hypertension in Ren-2 transgenic rats exposed to chronic hypoxia. Physiol Res. 2015;64(1):25-38.

13. Imai $\mathrm{Y}$, Kuba K, Ohto-Nakanishi $\mathrm{T}$, Penninger JM. Angiotensin-converting enzyme 2 (ACE2) in disease pathogenesis. Circ J. 2010;74(3):405-410.

14. Santos RAS, Sampaio WO, Alzamora AC, Motta-Santos D, Alenina N, Bader M, Campagnole-Santos MJ. The ACE2/ angiotensin-(1-7)/MAS axis of the renin-angiotensin system: Focus on angiotensin-(1-7). Physiol Rev. 2018;98:505-553.
15. Imai Y, Kuba K, Rao S, Huan Y, Guo F, Guan B, Yang P, Sarao R, Wada T, Leong-Poi H, Crackower MA, Fukamizu A, Hui CC, Hein L, Uhlig S, Slutsky AS, Jiang C, Penninger JM. Angiotensin-converting enzyme 2 protects from severe acute lung failure. Nature. 2005;436:112-116.

16. Li B, Yang J, Zhao F, et al. Prevalence and impact of cardiovascular metabolic diseases on COVID-19 in China. Clin Res Cardiol. 2020;109(5):531-538.

17. Gao C, Cai Y, Zhang K, et al. Association of hypertension and antihypertensive treatment with COVID-19 mortality: A retrospective observational study. Eur Heart J. 2020;41(22):2058-2066.

18. Klok FA, Kruip MJHA, van der Meer NJM, Arbous MS, Gommers DAMP, Kant KM, et al. Incidence of thrombotic complications in critically ill ICU patients with COVID-19. Thromb Res. 2020.

19. Nadar S, Lip GY. Hypertension and the prothrombotic state. J Am Coll Cardiol. 2003;41:1847.

20. Meng J, Xiao G, Zhang J, et al. Renin-angiotensin system inhibitors improve the clinical outcomes of COVID-19 patients with hypertension. Emerg Microbes Infect. 2020;9(1):757-760.

21. Zhang P, Zhu L, Cai J, et al. Association of Inpatient Use of Angiotensin Converting Enzyme Inhibitors and Angiotensin II Receptor Blockers with Mortality Among Patients With Hypertension Hospitalized With COVID-19. Circ Res. 2020;10.1161/CIRCRESAHA.120.317134.

22. Li J, Wang X, Chen J, Zhang H, Deng A. Association of ReninAngiotensin System Inhibitors With Severity or Risk of Death in Patients With Hypertension Hospitalized for Coronavirus Disease 2019 (COVID-19) Infection in Wuhan, China. JAMA Cardiol. 2020;e201624.

23. Richardson S, Hirsch JS, Narasimhan M, et al. Presenting Characteristics, Comorbidities, and Outcomes Among 5700 Patients Hospitalized With COVID-19 in the New York City Area. JAMA. 2020;323(20):2052-2059.

24. Pirola CJ, Sookoian S. Estimation of Renin-AngiotensinAldosterone-System (RAAS)-Inhibitor effect on COVID-19 outcome: A Meta-analysis. J Infect. 2020; S0163-4453(20) 30329-7.

25. Mancia G, Rea F, Ludergnani M, Apolone G, Corrao G. ReninAngiotensin-Aldosterone System Blockers and the Risk of Covid-19. N Engl J Med. 2020;NEJMoa2006923.

26. Tadic M, Cuspidi C, Mancia G, Dell'Oro R, Grassi G. COVID-19, hypertension and cardiovascular diseases: Should we change the therapy? Pharmacol Res. 2020;158:104906.

27. Hypertension ECo. Position Statement of the ESC Council on Hypertension on ACEInhibitors and Angiotensin Receptor Blockers. https://www.escardio.org/Councils/ Council-onHypertension-(CHT)/News/position-statement-of-the-esccouncilon-hypertension-on-ace-inhibitors-and-ang). 